\title{
Identifying Key Structural Subunits and Their Synergism in Low-Iridium Triple-Perovskites for Oxygen Evolution in Acidic Media
}

\author{
Qi Zhang, ${ }^{\mathrm{a}}$ Xiao Liang, ${ }^{\mathrm{a}}$ Hui Chen, ${ }^{\mathrm{a}}$ Wensheng Yan, ${ }^{\mathrm{b}}$ Lei Shi, ${ }^{\mathrm{a}}$ Yipu Liu, ${ }^{\mathrm{a}}$ \\ Jiayu $\mathrm{Li}^{\mathrm{a}}$ and Xiaoxin Zou, ${ }^{*, \mathrm{a}}$
}

\begin{abstract}
${ }^{a}$ State Key Laboratory of Inorganic Synthesis and Preparative Chemistry, College of Chemistry, Jilin University, Changchun 130012, P. R. China

${ }^{\mathrm{b}}$ National Synchrotron Radiation Laboratory, University of Science and Technology of China, Anhui 230029, P. R. China
\end{abstract}

*E-mail: xxzou@jlu.edu.cn 


\section{Experiment Section}

\section{Chemicals.}

Potassium hexachloroiridate(IV) $\left(\mathrm{K}_{2} \mathrm{IrCl}_{6}, 99.99 \%\right)$, iridium (Ir powder, 99.99\%) and indium(III) oxide $\left(\mathrm{In}_{2} \mathrm{O}_{3}\right)$ were purchased from Aladdin industrial Corporation. Ruthenium (Ru powder, 99.9\%) was purchased from Shanghai Macklin Biochemical Co., Ltd. Barium carbonate $\left(\mathrm{BaCO}_{3}\right)$, tetrabutyl titanate $\left(\mathrm{C}_{16} \mathrm{H}_{36} \mathrm{O}_{4} \mathrm{Ti}\right)$ and ethylene glycol $\left(\left(\mathrm{CH}_{2} \mathrm{OH}\right)_{2}\right)$ were purchased from Sinopharm Chemical Reagent Co., Ltd. Titanium dioxide $\left(\mathrm{TiO}_{2}\right)$, citric acid monohydrate $\left(\mathrm{C}_{6} \mathrm{H}_{8} \mathrm{O}_{7} \cdot \mathrm{H}_{2} \mathrm{O}\right)$, isopropyl alcohol $\left(\left(\mathrm{CH}_{3}\right)_{2} \mathrm{CHOH}\right)$, ethanol absolute $\left(\mathrm{C}_{2} \mathrm{H}_{6} \mathrm{O}\right)$ and hydrochloric acid $(\mathrm{HCl})$ were purchased from Beijing Chemical Factory. Zinc oxide was purchased from Tianjin Jinfeng Chemical Co., Ltd. Barium acetate $\left(\left(\mathrm{CH}_{3} \mathrm{COO}\right)_{2} \mathrm{Ba}\right)$ was purchased from Tianjin Guangfu Fine Chemical Co., Ltd. Perchloric acid $\left(\mathrm{HClO}_{4}, 70.0-72.0 \%\right)$ was purchased from Tianjin Xinyuan Chemical Co., Ltd. Nafion ${ }^{\circledR}$ perfluorinated resin solution was purchased from Sigma-Aldrich. Highly purified water $(>18 \mathrm{M} \mathrm{cm}$ resistivity) was provided by a PALL PURELAB Plus system.

\section{Theoretical Section}

\section{Calculation models.}

The bulk model of the $\mathrm{Ba}_{3} \mathrm{TiIr}_{2} \mathrm{O}_{9}$ was constructed according to the Doi et al. ${ }^{1}$. After optimization, three possible surface models were obtained by cleaving (001) facets of $\mathrm{Ba}_{3} \operatorname{TiIr}_{2} \mathrm{O}_{9}$, with a vacuum space of $15 \AA$ to avoid interaction between periodic images. The upper four atomic layers of the slab models were fully relaxed and the remaining layers were fixed for the following calculations. The schematic structural slab models of three surfaces were shown in Figure 5a-b, and Figure S9.

The OER performance for these slab models were estimated by using the approach proposed by Nørskov et al. ${ }^{2}$, where OER included four elementary reaction steps with $\mathrm{HO}^{*}, \mathrm{O}^{*}$, and $\mathrm{HOO}^{*}$ as intermediates.

$$
\mathrm{H}_{2} \mathrm{O}(\mathrm{l})+* \rightarrow \mathrm{OH}^{*}+\mathrm{H}^{+}+\mathrm{e}^{-}
$$




$$
\begin{aligned}
& \mathrm{OH}^{*} \rightarrow \mathrm{O}^{*}+\mathrm{H}^{+}+\mathrm{e}^{-} \\
& \mathrm{H}_{2} \mathrm{O}(\mathrm{l})+\mathrm{O}^{*} \rightarrow \mathrm{OOH}^{*}+\mathrm{H}^{+}+\mathrm{e}^{-} \\
& \mathrm{OOH}^{*} \rightarrow *+\mathrm{O}_{2}(\mathrm{~g})+\mathrm{H}^{+}+\mathrm{e}^{-}
\end{aligned}
$$

where $*$ represents surface active sites, and $\mathrm{OH}^{*}, \mathrm{O}^{*}$, and $\mathrm{OOH}^{*}$ are the absorbed intermediates on the surface.

The free energy of each step is calculated by the following equation:

$$
\begin{aligned}
& \Delta G_{1}=E\left(\mathrm{OH}^{*}\right)-E(*)-E_{\mathrm{H} 2 \mathrm{O}}+1 / 2 E_{\mathrm{H} 2}+(\Delta Z P E-T \Delta S)_{1}-e U \\
& \Delta G_{2}=E\left(\mathrm{O}^{*}\right)-E\left(\mathrm{OH}^{*}\right)+1 / 2 E_{\mathrm{H} 2}+(\Delta Z P E-T \Delta S)_{2}-e U \\
& \Delta G_{3}=E\left(\mathrm{OOH}^{*}\right)-E\left(\mathrm{O}^{*}\right)-E_{\mathrm{H} 2 \mathrm{O}}+1 / 2 E_{\mathrm{H} 2}+(\Delta Z P E-T \Delta S)_{3}-e U \\
& \Delta G_{4}=E(*)-E\left(\mathrm{OOH}^{*}\right)+E_{\mathrm{O} 2}+1 / 2 E_{\mathrm{H} 2}+(\Delta Z P E-T \Delta S)_{4}-e U
\end{aligned}
$$

where $E(*), E\left(\mathrm{OH}^{*}\right), E\left(\mathrm{O}^{*}\right)$ and $E\left(\mathrm{OOH}^{*}\right)$ represent the total energies of clean surface and absorbed surface with $\mathrm{OH} *, \mathrm{O}^{*}$ and $\mathrm{OOH}^{*}$ intermediates, respectively. $E_{\mathrm{H} 2}, E_{\mathrm{O} 2}$ and $E_{\mathrm{H} 2 \mathrm{O}}$ are computed energies for single $\mathrm{H}_{2}, \mathrm{O}_{2}$ and $\mathrm{H}_{2} \mathrm{O}$. The free energy change was fixed at the experimental value of $2.46 \mathrm{eV}$ according to the reaction of $\mathrm{H}_{2} \mathrm{O} \rightarrow 1 / 2 \mathrm{O}_{2}$ $+\mathrm{H}_{2} . \triangle Z P E, T \Delta S$ and $e U$ represent the zero point energy changes, the entropy changes and the external bia $\mathrm{U}$ imposed on each step.

The ELF is used to acquire the localized orbitals to describe bonding characteristics in crystal structures. The ELF image is represented by a contour plot with the range from 0 to 1 . The blue region close to 0 implies a low electron density area, while the red region close to 1 implies the existence of strong covalent electrons or lone-pair electrons. The region close to 0.5 is on behalf of homogeneous electron gas or metallic bonds. As shown in Figure $1 \mathrm{~b}$, Ir-Ir bond in $\operatorname{Ir}_{2} \mathrm{O}_{9}$ dimers exhibits a correlative ELF value with a range of 0.4 to 0.5 , which indicates Ir-Ir bonding has metallic features. ${ }^{3,4}$

O $2 p$-band center $\left(\varepsilon_{2 p}\right)$ relative to the Fermi level was obtained by using the equation as below: ${ }^{5}$ 


$$
\varepsilon_{2 p}=\frac{\int_{-\infty}^{+\infty} \mathrm{n}_{2 p}(\varepsilon) \varepsilon \mathrm{d} \varepsilon}{\int_{-\infty}^{+\infty} \mathrm{n}_{2 p}(\varepsilon) \mathrm{d} \varepsilon}
$$

where $\varepsilon$ is the energy referring to E-Fermi, and $\mathrm{n}_{2 p}(\varepsilon)$ is the projected density of states (PDOS) for O-2p orbital.
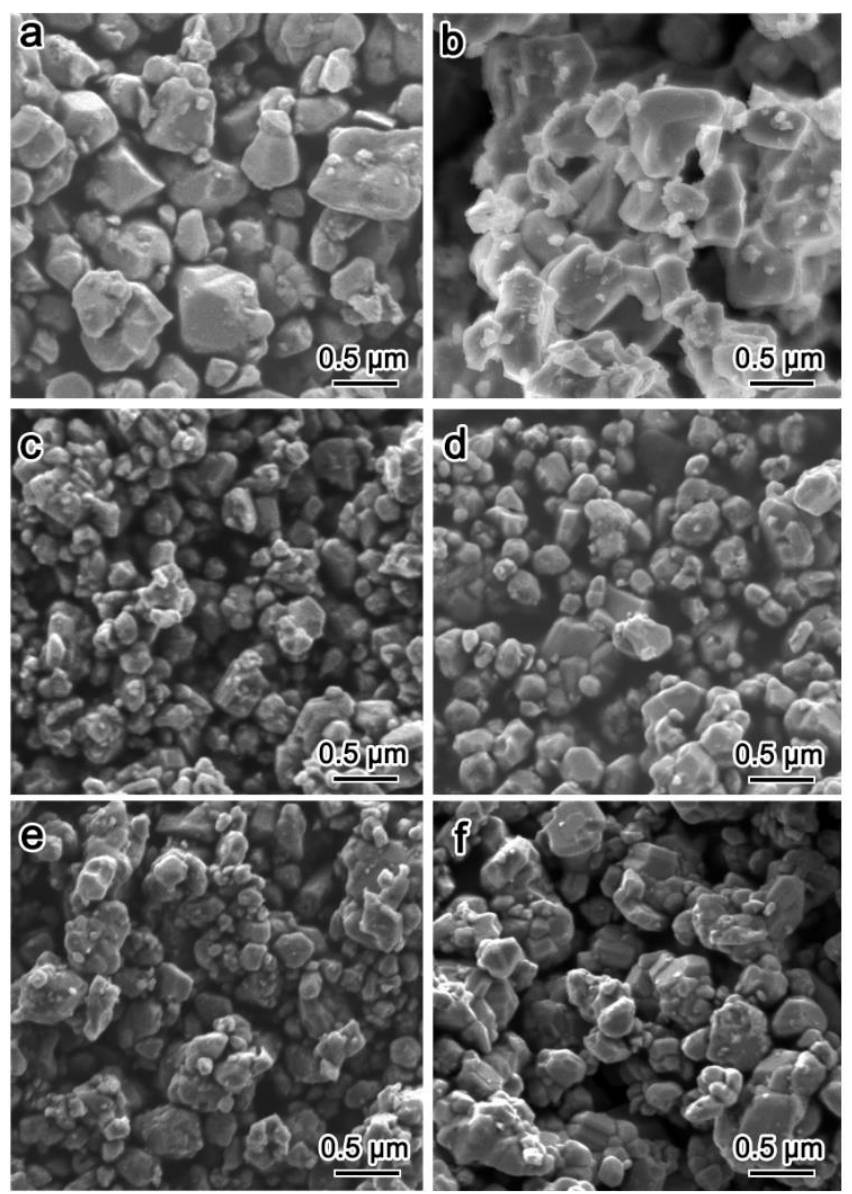

Figure S1. SEM images of (a) $\mathrm{Ba}_{3} \mathrm{ZnIr}_{2} \mathrm{O}_{9}$, (b) $\mathrm{Ba}_{3} \mathrm{InIr}_{2} \mathrm{O}_{9}$, (c) $\mathrm{Ba}_{3} \mathrm{TiIr}_{2} \mathrm{O}_{9}$, (d) $\mathrm{Ba}_{3} \mathrm{TiTiIrO}_{9}$, (e) $\mathrm{Ba}_{3} \mathrm{TiIrRuO}_{9}$ and (f) $\mathrm{Ba}_{3} \mathrm{TiRu}_{2} \mathrm{O}_{9}$. 

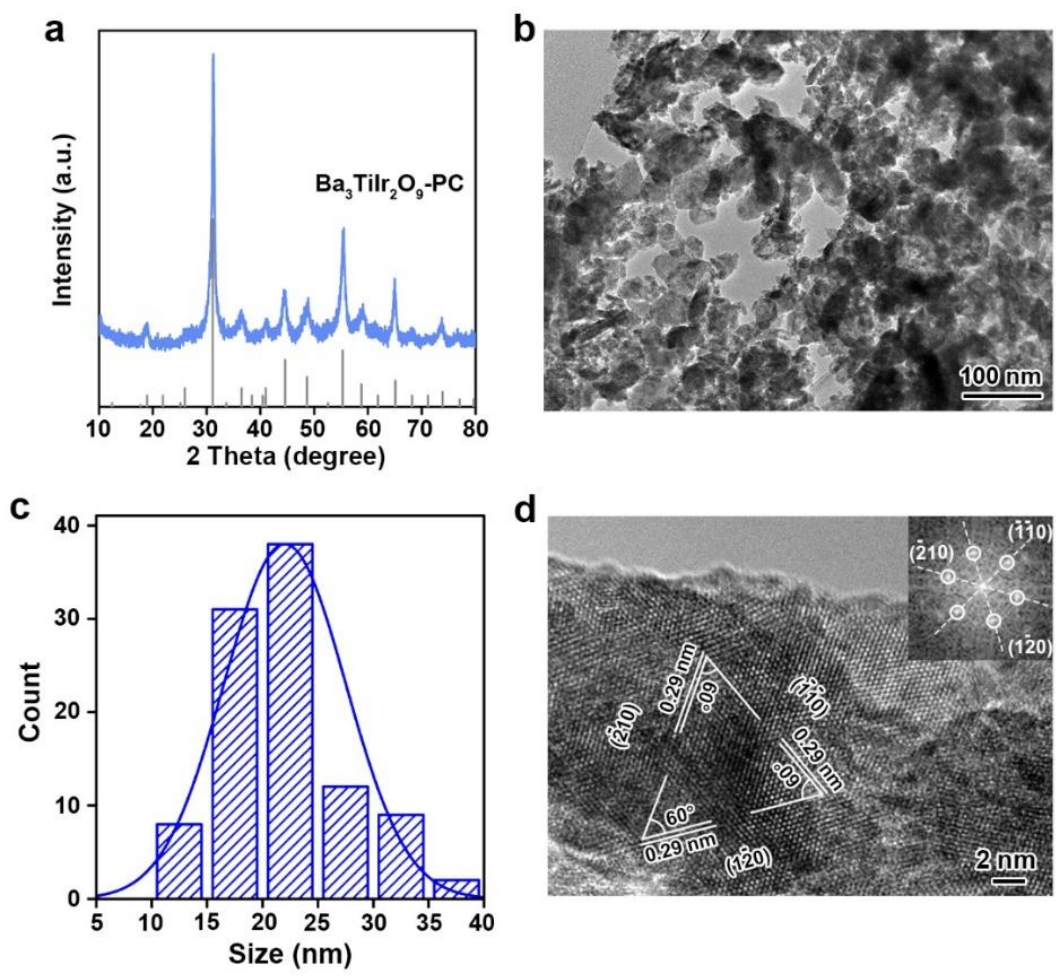

Figure S2. (a) XRD pattern, (b) TEM image, (c) the corresponding particle size distribution and (d) HRTEM image of $\mathrm{Ba}_{3} \mathrm{TiIr}_{2} \mathrm{O}_{9}-\mathrm{PC}$. Inset in (d) is the corresponding fast Fourier transform image.

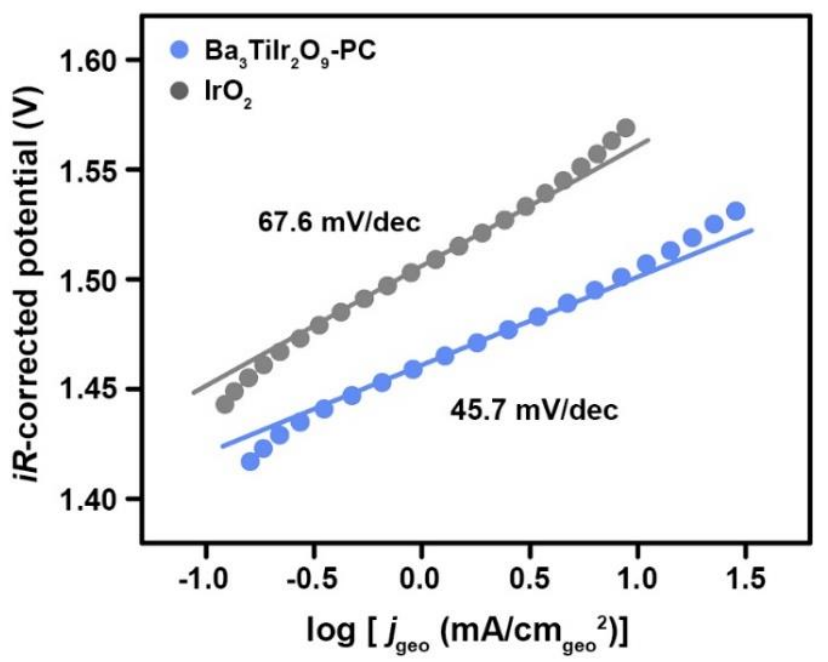

Figure S3. Tafel plots of $\mathrm{Ba}_{3} \mathrm{TiIr}_{2} \mathrm{O}_{9}-\mathrm{PC}$ and $\mathrm{IrO}_{2}$ for OER. 

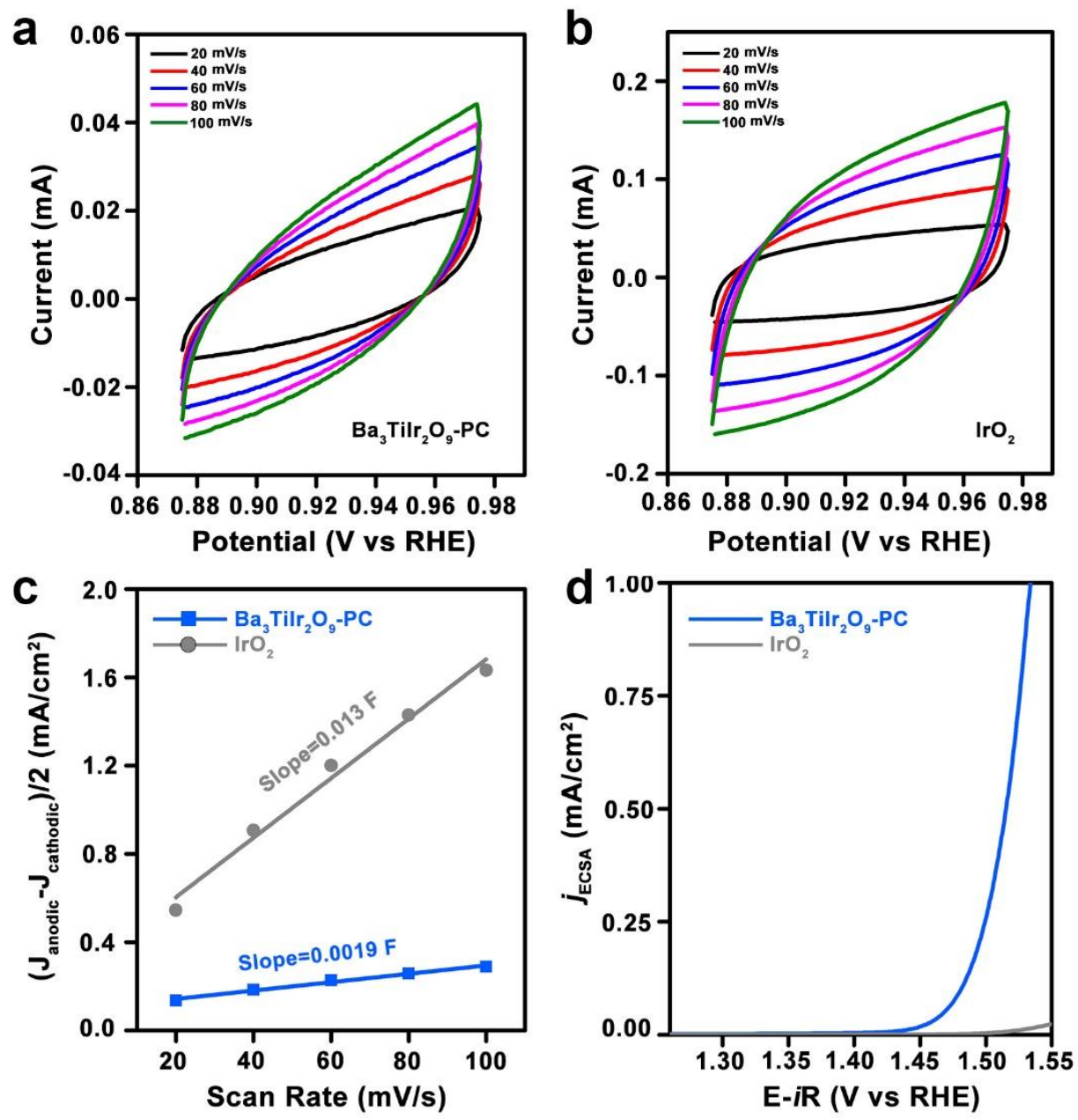

Figure S4. (a) Cyclic voltammograms of $\mathrm{Ba}_{3} \mathrm{TiIr}_{2} \mathrm{O}_{9}-\mathrm{PC}$ measured in a non-Faradaic region of the voltammogram at different scan rates. (b) Cyclic voltammograms of $\mathrm{IrO}_{2}$ measured in a non-Faradaic region of the voltammogram at different scan rates. (c) The difference in current density between the anodic and cathodic versus scan rate. The slope represents the geometric double layer capacitance $\left(\mathrm{C}_{\mathrm{dl}}\right)$. (d) Polarization curves normalized by the effective electrochemical active surface area toward OER of $\mathrm{Ba}_{3} \mathrm{TiIr}_{2} \mathrm{O}_{9}-\mathrm{PC}$ and $\mathrm{IrO}_{2}$ in $0.1 \mathrm{M} \mathrm{HClO}_{4}$ solution. 


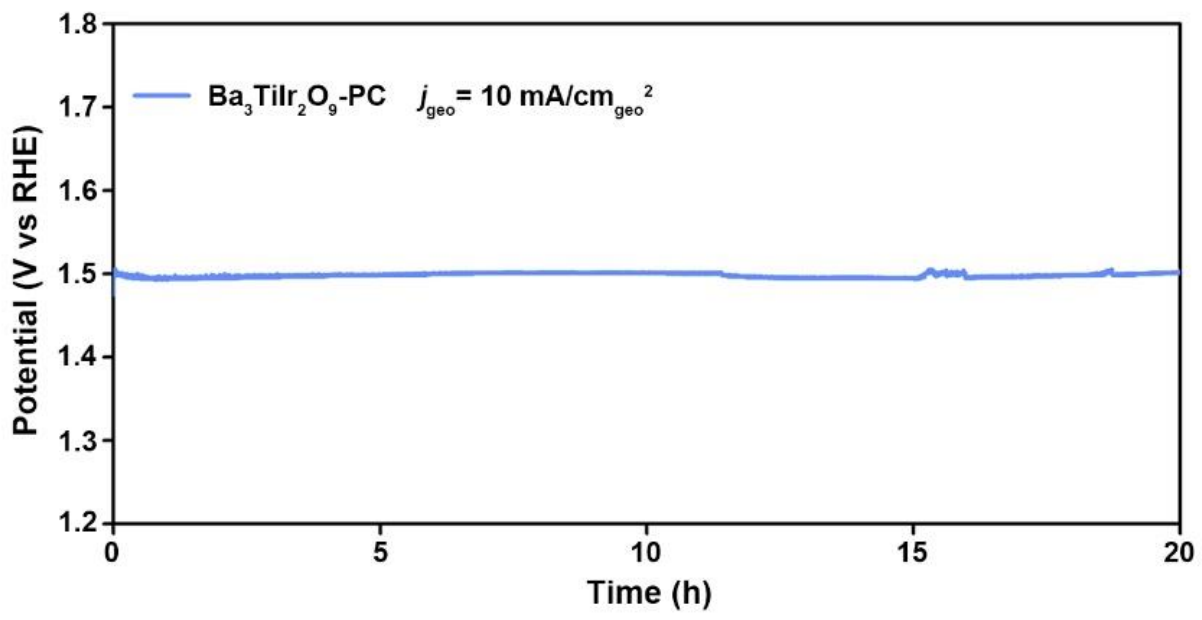

Figure S5. Chronopotentiometric curve of $\mathrm{Ba}_{3} \mathrm{TiIr}_{2} \mathrm{O}_{9}-\mathrm{PC}$ for $\mathrm{OER}$ at $10 \mathrm{~mA} \mathrm{~cm}^{-2}$ geo.
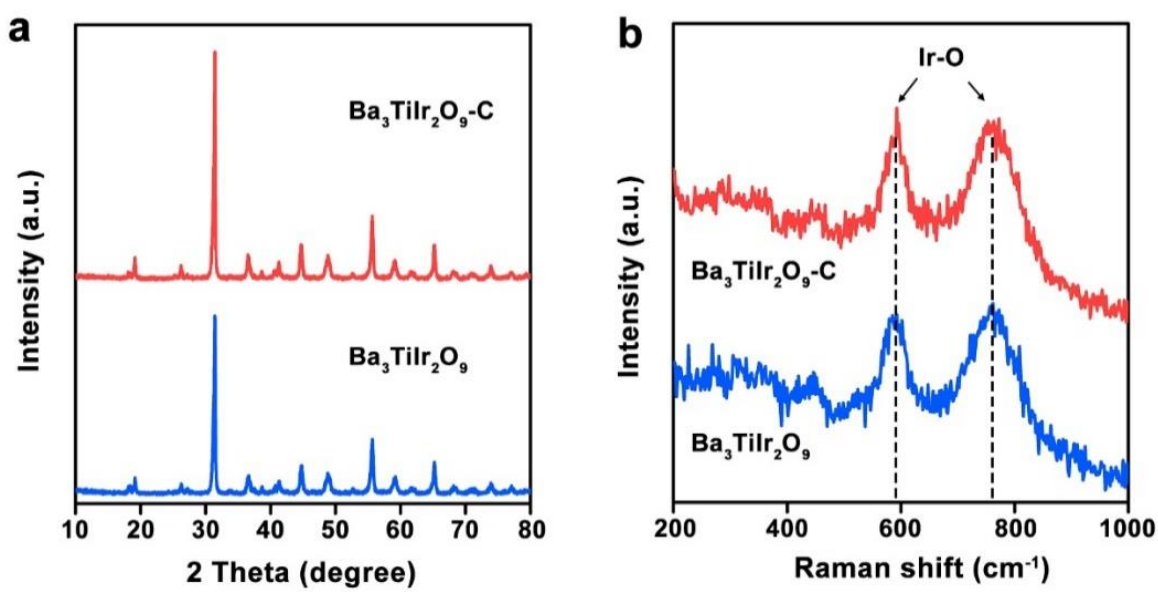

Figure S6. Comparison of (a) XRD patterns and (b) Raman spectra of $\mathrm{Ba}_{3} \mathrm{TiIr}_{2} \mathrm{O}_{9}$ and the $\mathrm{Ba}_{3} \mathrm{TiIr}_{2} \mathrm{O}_{9}$ after $10 \mathrm{~h}$ OER at $10 \mathrm{~mA} / \mathrm{cm}_{\text {geo }}{ }^{2}\left(\mathrm{Ba}_{3} \mathrm{TiIr}_{2} \mathrm{O}_{9}-\mathrm{C}\right)$. 


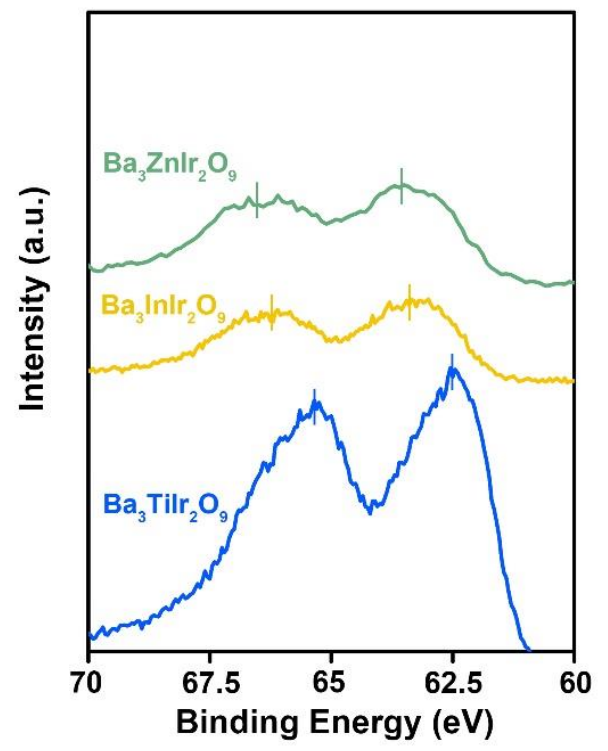

Figure S7. Ir 4f XPS spectra for $\mathrm{Ba}_{3} \mathrm{M}^{\prime} \mathrm{Ir}_{2} \mathrm{O}_{9}\left(\mathrm{M}^{\prime}=\mathrm{Zn}\right.$, In, Ti $)$.

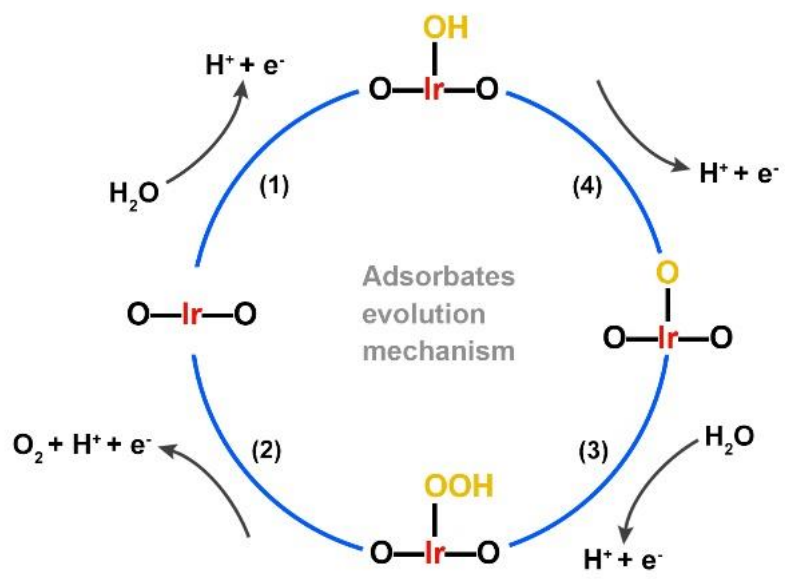

Figure S8. The Schematic diagram for OER mechanism on the surface of $\mathrm{Ba}_{3} \mathrm{TiIr}_{2} \mathrm{O}_{9}$. 


\section{Surface-Ti}

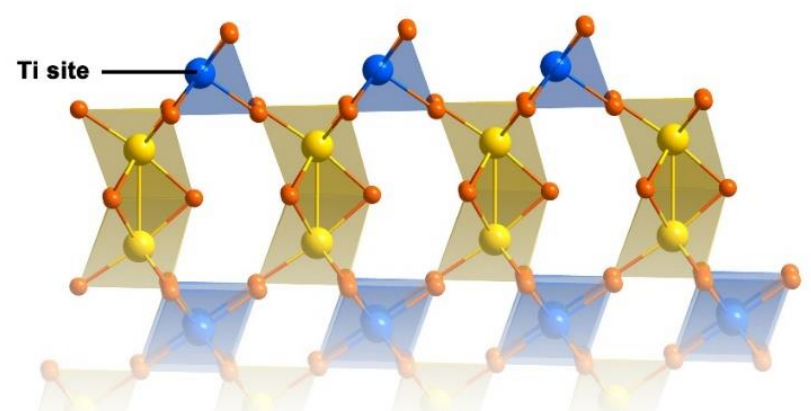

Figure S9. Structural model of $\mathrm{Ba}_{3} \mathrm{TiIr}_{2} \mathrm{O}_{9}$ with the possible exposed Surface-Ti. Ba atoms are not shown in the model for clarity. 
Table S1. Comparison of OER activities and the mass activity of $\mathrm{Ba}_{3} \mathrm{TiIr}_{2} \mathrm{O}_{9}$ with previously-reported iridium-based catalysts in acid.

\begin{tabular}{|c|c|c|c|c|}
\hline Catalysts & Electrolytes & $\begin{array}{c}\eta \text { at } 10 \mathrm{~mA} / \\
\mathrm{cm}^{2}{ }_{\text {geo }}\end{array}$ & $\begin{array}{l}\mathrm{j}\left(\mathrm{A} \mathrm{g} \mathrm{g}^{-1} \mathrm{Ir}\right) @ \eta= \\
300 \mathrm{mV} \text { vs RHE }\end{array}$ & Reference \\
\hline $\mathrm{Ba}_{3} \mathrm{TiIr}_{2} \mathrm{O}_{9}-\mathrm{PC}$ & $0.1 \mathrm{M} \mathrm{HClO}_{4}$ & $275 \mathrm{mV}$ & 250 & This work \\
\hline $\mathrm{IrO}_{2}$ & $0.1 \mathrm{M} \mathrm{HClO}_{4}$ & $345 \mathrm{mV}$ & 9 & This work \\
\hline $\mathrm{Bi}_{2} \mathrm{Ir}_{2} \mathrm{O}_{7}$ & $1 \mathrm{M} \mathrm{H}_{2} \mathrm{SO}_{4}$ & $\begin{array}{c}340-370 \\
\mathrm{mV}\end{array}$ & $\sim 1.9$ & $\begin{array}{l}\text { Chem. Mater. } \\
\text { 2012, 24, } 4192\end{array}$ \\
\hline $\mathrm{Y}_{2} \mathrm{Ir}_{2} \mathrm{O}_{7}$ & $\begin{array}{l}0.1 \mathrm{M} \mathrm{HClO}_{4} \\
\text { or } 1 \mathrm{M} \mathrm{H}_{2} \mathrm{SO}_{4}\end{array}$ & $>370 \mathrm{mV}$ & $\begin{array}{l}10 \mathrm{~A} \mathrm{~g}^{-1} \text { Ir at } 1.5 \\
\mathrm{~V}\end{array}$ & $\begin{array}{l}\text { Chem. Mater. } \\
\mathbf{2 0 1 7}, 29,5182\end{array}$ \\
\hline $\mathrm{Nd}_{2} \mathrm{Ir}_{2} \mathrm{O}_{7}$ & $0.1 \mathrm{M} \mathrm{HClO}_{4}$ & $\sim 330 \mathrm{mV}$ & 156.3 & $\begin{array}{c}\text { Adv. Mater. } \\
\text { 2018, } 31 \\
1805104\end{array}$ \\
\hline $\mathrm{Gd}_{2} \mathrm{Ir}_{2} \mathrm{O}_{7}$ & $0.1 \mathrm{M} \mathrm{HClO}_{4}$ & $\sim 350 \mathrm{mV}$ & 73.0 & $\begin{array}{c}\text { Adv. Mater. } \\
\text { 2018, 31 } \\
1805104\end{array}$ \\
\hline $\mathrm{Tb}_{2} \mathrm{Ir}_{2} \mathrm{O}_{7}$ & $0.1 \mathrm{M} \mathrm{HClO}_{4}$ & $\sim 370 \mathrm{mV}$ & 51.2 & $\begin{array}{c}\text { Adv. Mater. } \\
\text { 2018, 31, } \\
1805104\end{array}$ \\
\hline $\mathrm{Ho}_{2} \mathrm{Ir}_{2} \mathrm{O}_{7}$ & $0.1 \mathrm{M} \mathrm{HClO}_{4}$ & $\sim 380 \mathrm{mV}$ & 36.2 & $\begin{array}{c}\text { Adv. Mater. } \\
\mathbf{2 0 1 8}, 31 \\
1805104\end{array}$ \\
\hline $\mathrm{La}_{2} \mathrm{LiIrO}_{6}$ & $0.1 \mathrm{M} \mathrm{H}_{2} \mathrm{SO}_{4}$ & $\sim 300 \mathrm{mV}$ & $\begin{array}{c}10 \mathrm{~A} \mathrm{~g}^{-1} \text { Ir at } 1.5 \\
\mathrm{~V}\end{array}$ & $\begin{array}{c}\text { Nat. Energy } \\
\text { 2016, } 2,16189 \\
\end{array}$ \\
\hline $6 \mathrm{H}-\mathrm{SrIrO}_{3}$ & $0.5 \mathrm{M} \mathrm{H}_{2} \mathrm{SO}_{4}$ & $248 \mathrm{mV}$ & $\sim 75$ & $\begin{array}{l}\text { Nat. Commun. } \\
\mathbf{2 0 1 8}, 9,5236\end{array}$ \\
\hline $\begin{array}{l}3 \mathrm{C}-\mathrm{SrIrO}_{3} \text { (or } \\
\mathrm{IrO}_{\mathrm{x}} / \mathrm{SrIrO}_{3} \text { ) }\end{array}$ & $0.5 \mathrm{M} \mathrm{H}_{2} \mathrm{SO}_{4}$ & $\begin{array}{c}270-290 \\
\mathrm{mV}\end{array}$ & l & $\begin{array}{c}\text { Science } \\
\mathbf{2 0 1 6}, 353,1011 \\
\end{array}$ \\
\hline $\mathrm{W}_{0.57} \mathrm{Ir}_{0.43} \mathrm{O}_{3-\sigma}$ & $1 \mathrm{M} \mathrm{H}_{2} \mathrm{SO}_{4}$ & $\begin{array}{c}370 \pm 2 \\
\mathrm{mV}\end{array}$ & 1.46 & $\begin{array}{c}\text { Energy } \\
\text { Environ. Sci., } \\
\mathbf{2 0 1 7}, 10,2432\end{array}$ \\
\hline $\mathrm{Ba}_{2} \mathrm{NdIrO}_{6}$ & $0.1 \mathrm{M} \mathrm{HClO}_{4}$ & $>400 \mathrm{mV}$ & $\sim 2.8$ & $\begin{array}{l}\text { Nat. Commun. } \\
\text { 2016, 7, } 12363\end{array}$ \\
\hline $\mathrm{Li}-\mathrm{IrOx}$ & $0.5 \mathrm{M} \mathrm{H}_{2} \mathrm{SO}_{4}$ & $290 \mathrm{mV}$ & l & $\begin{array}{l}\text { J. Am. Chem. } \\
\text { Soc. 2019, 141, } \\
3014\end{array}$ \\
\hline $\mathrm{IrO}_{2}-\mathrm{TiO}_{2}-245$ & $0.1 \mathrm{M} \mathrm{HClO}_{4}$ & / & $\sim 70$ & $\begin{array}{c}\text { ACS Catal. } \\
\mathbf{2 0 1 7}, 7,2346\end{array}$ \\
\hline $\begin{array}{l}\mathrm{Co}-\mathrm{IrCu} \\
\mathrm{ONC} / \mathrm{C}\end{array}$ & $0.1 \mathrm{M} \mathrm{HClO}_{4}$ & $293 \mathrm{mV}$ & I & $\begin{array}{c}\text { Adv. Funct. } \\
\text { Mater. 2017, } \\
\text { 27, } 1604688\end{array}$ \\
\hline $\begin{array}{l}\text { Amorphous } \\
\text { Ir/C NSs }\end{array}$ & $0.1 \mathrm{M} \mathrm{HClO}_{4}$ & $255 \mathrm{mV}$ & 221.8 & $\begin{array}{l}\text { Nat. Commun. } \\
\text { 2019, 10, } 4855\end{array}$ \\
\hline
\end{tabular}




\begin{tabular}{|c|c|c|c|c|}
\hline $\begin{array}{c}\text { Crystalline } \\
\text { Ir/C NSs }\end{array}$ & $0.1 \mathrm{M} \mathrm{HClO}_{4}$ & $280 \mathrm{mV}$ & 88.7 & $\begin{array}{c}\text { Nat. Commun. } \\
\mathbf{2 0 1 9}, 10,4855\end{array}$ \\
\hline $\mathrm{IrNi} / \mathrm{C}$ & $0.1 \mathrm{M} \mathrm{HClO}_{4}$ & $260 \mathrm{mV}$ & $\sim 200$ & Adv. Mater. \\
& & & & $\mathbf{2 0 1 7}, 29$, \\
& & & & 1703798 \\
\hline
\end{tabular}

Table S2. The free energies for absorbed $\mathrm{OH}, \mathrm{O}, \mathrm{OOH}$ intermediates and the overpotentials of the metal sites on the three possible surfaces.

\begin{tabular}{lllll}
\hline & $\Delta G_{\mathrm{OH}^{*}}(\mathrm{eV})$ & $\Delta G_{\mathrm{O}^{*}}(\mathrm{eV})$ & $\Delta G_{\mathrm{OOH}^{*}}(\mathrm{eV})$ & $\eta(\mathrm{OER})$ \\
\hline Surface-Ti & -1.00 & 0.57 & 1.86 & $1.83 \mathrm{~V}$ \\
Surface-Ir1 & 0.28 & 1.93 & 3.39 & $0.42 \mathrm{~V}$ \\
Surface-Ir2 & 0.45 & 1.59 & 3.38 & $0.56 \mathrm{~V}$ \\
\hline
\end{tabular}




\section{References in SI}

1. Sakamoto, T., Doi, Y. \& Hinatsu, Y. Crystal structures and magnetic properties of 6H-perovskite-type oxides $\mathrm{Ba}_{3} \mathrm{MIr}_{2} \mathrm{O}_{9}(\mathrm{M}=\mathrm{Mg}, \mathrm{Ca}, \mathrm{Sc}, \mathrm{Ti}, \mathrm{Zn}, \mathrm{Sr}, \mathrm{Zr}, \mathrm{Cd}$ and In). $J$. Solid State Chem. 2006, 179, 2595-2601.

2. Rossmeisl, J., Qu, Z. W., Zhu, H., Kroes, G. J. \& Nørskov, J. K. Electrolysis of water on oxide surfaces. J. Electroanal. Chem. 2007, 607, 83-89.

3. Savin, A., Jepsen, O., Flad, J., Andersen, O. K., Preuss, H. \& Schnering, H. G. Electron Localization in Solid-State Structures of the Elements: the Diamond Structure Electrolysis of water on oxide surfaces. Angew. Chem. Int. Ed., 1992, 31, 187-188.

4. Yang, L. et al. Efficient oxygen evolution electrocatalysis in acid by a perovskite with face-sharing $\mathrm{IrO}_{6}$ octahedral dimers. Nat. Commun. 2018, 9, 5236.

5. Montoya, J. H., Doyle, A. D., Nørskov, J. K. \& Vojvodic, A. Trends in adsorption of electrocatalytic water splitting intermediates on cubic $\mathrm{ABO}_{3}$ oxides. Phys. Chem. Chem. Phys. 2018, 20, 3813-3818. 